\title{
Widespread distribution of bronchopulmonary endocrine cells immunoreactive for calcitonin in the lung of the normal adult rat
}

\author{
JOHN R GOSNEY, MCJ SISSONS \\ From the Department of Pathology, University of Liverpool
}

\begin{abstract}
The nature and distribution of bronchopulmonary endocrine cells immunoreactive for calcitonin was studied in normal adult Wistar albino rats by immunoenzyme histochemistry with the peroxidase-antiperoxidase technique. A widespread distribution of both solitary endocrine cells and neuroepithelial bodies immunoreactive for calcitonin was found. Many, but not all, were also immunoreactive for neurone specific enolase. Although both classes of cells were present in airways and parenchyma, most of the solitary cells were found in alveolar ducts and alveoli whereas most of the neuroepithelial bodies were located in bronchi and bronchioles. Bronchopulmonary endocrine cells are generally regarded as being sparse in the adult rat. It is suggested that this may be a consequence of the use of inadequate methods in attempting to identify them. So far as is known, this is the first time that calcitonin has been demonstrated by immunohistochemical methods in the lungs of rats.
\end{abstract}

The function of the endocrine cells of the respiratory tract in health and disease is still largely unknown, despite the large amount of work which has been carried out since they were first described by Feyrter' and Fröhlich ${ }^{2}$ some 30 years ago. Amines, such as 5-hydroxytryptamine (5-HT, serotonin), ${ }^{3}$ and peptides, such as calcitonin, gastrin releasing peptide, and leu-enkephalin, ${ }^{4}$ have been found in these cells in man, which may be solitary or grouped. The latter, which are innervated structures, have been termed neuroepithelial bodies. ${ }^{5}$ There is some evidence to support the inclusion of both of these types in the APUD system of secretory cells. ${ }^{6}$

Although endocrine cells have been described in the lungs of many species, the adult rat is generally regarded as possessing few and therefore as being unsuitable for such studies. ${ }^{78}$ In addition, so far as we are aware, calcitonin has never been found within the endocrine cells of the lungs of this species. The aim of this study was to investigate the pattern and extent of distribution of endocrine cells immunoreactive for calcitonin in the lungs of normal adult Wistar albino rats.

Address for reprint requests: Dr JR Gosney, University Department of Pathology, Duncan Building, Royal Liverpool Hospital, Prescot Street, Liverpool L7 8XP.

Accepted 24 September 1984

\section{Methods}

Six healthy adult Wistar albino rats, three of them males, were killed by dislocation of the cervical vertebrae, the thoraces opened, and the lungs removed intact. The latter were gently distended with freshly prepared Bouin's solution by means of a cannula placed in the trachea, and allowed to fix for four hours only. Then each lung was cut with a razor blade into six tissue blocks of equal thickness in the parasagittal plane, thus providing 12 closely similar samples from each animal. These were embedded in paraffin wax and groups of sections, each $4 \mu \mathrm{m}$ in thickness, were taken for study from each block. The adjacent sections were stained with haematoxylin and eosin and labelled for calcitonin by the peroxidase antiperoxidase method. ${ }^{9}$

For the latter procedure we used four different commercially available polyclonal antisera to synthetic human calcitonin raised in rabbit (Ortho Ltd, Steranti Research Ltd, Bionuclear Services Ltd, Dako Corporation). As this study was carried out in the rat, the antisera were heterologous, but crossreactivity with rat calcitonin, which is closely similar in its peptide sequence to human calcitonin, was between $96-99 \%$ as determined by radioimmunoassay. The working dilution of primary antiserum in all cases was 1:8000 with overnight (18 
hour) incubation at $4^{\circ} \mathrm{C}$. All antisera showed $100 \%$ crossreactivity with purified antigen, but none more than $0.1 \%$ with other purified peptide hormones as determined by radioimmunoassay. In all cases liquid phase absorption studies were performed with incubation for 18 hours at $4^{\circ} \mathrm{C}$, in which each antiserum was incubated with varying concentrations of purified calcitonin, katacalcin and calcitonin gene related peptide. The addition of $0.1 \%$ bovine serum albumin prevented non-specific absorption of the antisera. In all cases complete quenching of immunostaining was obtained with 25-100 ng of calcitonin. Katacalcin and calcitonin gene related peptide had no effect on staining at concentrations of up to $100 \mu \mathrm{g}$.

The primary antisera were linked to rabbit immunoglobulin peroxidase complex (PAP) diluted 1:200 by swine antirabbit serum diluted 1:20. The reaction product that followed addition of hydrogen peroxide was demonstrated by means of 3-amino 9 -ethylcarbazole. This gives a red brown precipitate. All sera and other solutions were diluted in phosphate buffered saline. Endogenous peroxidase was removed by the addition of $1 \%$ hydrogen peroxide in methanol for half an hour, and non-specific binding of immunoglobulin was inhibited by the addition of normal swine serum. Negative control procedures required omission of each stage of the procedure in turn and replacement of the primary anticalcitonin antisera with antisera to other peptide hormones. Positive tissue controls consisted of the immunostaining of sections of human and non-human thyroid gland and lung, and of tissue from human medullary carcinoma of the thyroid.

Adjacent sections to those used in the above procedure were immunostained for neurone specific enolase using two different antisera (Polyscience Ltd, Dako Corporation), also by application of the peroxidase antiperoxidase method. This acidic isoenzyme, formerly considered confined to

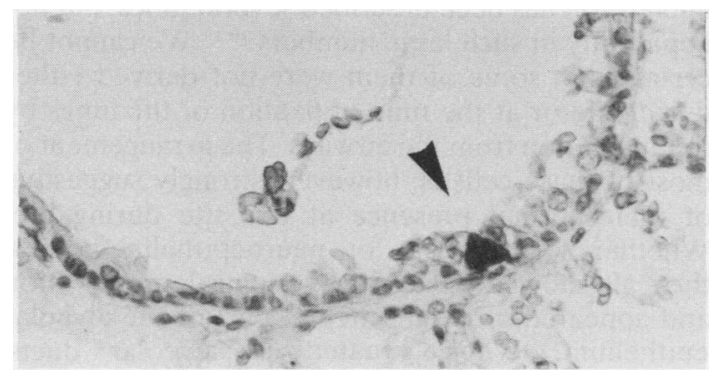

Fig 1 Part of a terminal bronchiole containing a solitary endocrine cell immunoreactive for calcitonin (arrow). Note the characteristic pyramidal morphology. (Peroxidase antiperoxidase, anticalcitonin; $\times 330$.) neurones, is now thought to provide a marker for neuroendocrine cells.

Several different attempts at quantitative measurement of pulmonary endocrine cell populations have been made in the past ${ }^{1011}$ and they do not permit accurate comparison between different studies. In view of this, and of the fact that we were not making comparisons between different experimental groups, we did not attempt to quantify the population of endocrine cells immunoreactive for calcitonin, but simply assessed them according to their presence in either bronchi and bronchioles or alveolar ducts and alveoli.

\section{Results}

The cytoplasm of immunoreactive cells showed strong granular staining with all antisera used and they were in all cases easily distinguished from nonreacting components. Solitary endocrine cells and neuroepithelial bodies immunoreactive for calcitonin were widespread in the airways and alveoli of all animals. Both of these components were morphologically typical of bronchopulmonary endocrine cells. ${ }^{12}{ }^{13}$ The single cells were mostly pyramidal and situated close to the basement membrane. When located in an airway they usually appeared to be buried deep within the epithelium, apparently failing to reach the lumen (fig 1). Occasionally they occurred in small runs of two or three adjacent cells. The distinction between such small aggregates and true neuroepithelial bodies was not difficult to make since the former, though comprising more than one cell, show none of the typical features of these structures. Neuroepithelial bodies were characteristically corpuscular in morphology, comprising from four to as many as 26 cuboidal or columnar cells parallel to each other and closely packed (figs 2 and 3 ). In con-

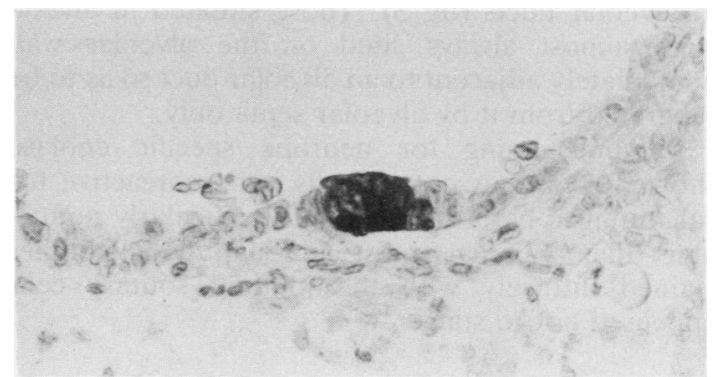

Fig 2 Part of a terminal bronchiole containing a neuroepithelial body immunoreactive for calcitonin. Note the corpuscular appearance and columnar morphology of its constituent cells. (Peroxidase antiperoxidase, anticalcitonin; $\times 375$.) 


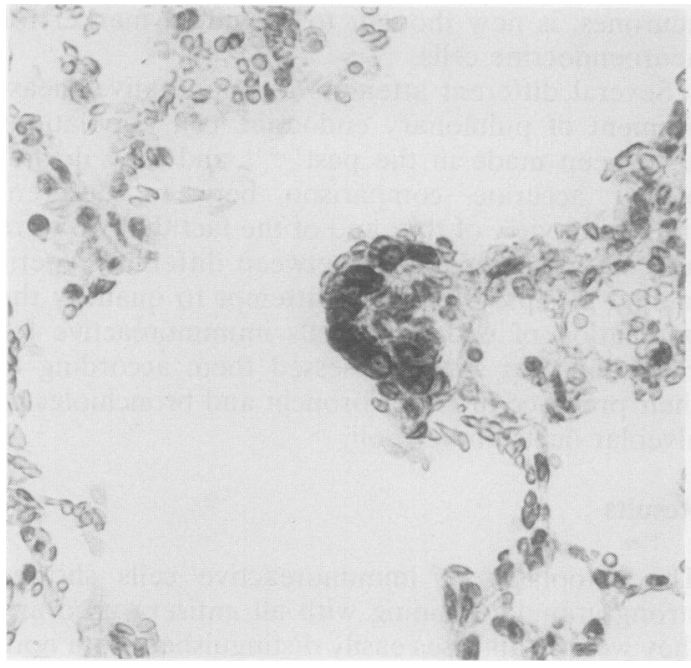

Fig 3 Alveolar duct containing a neuroepithelial body immunoreactive for calcitonin. Note its situation over an elevation in the wall of the duct. (Peroxidase antiperoxidase, anticalcitonin; $\times 375$.)

trast to the singly occurring cells, they were in obvious contact with the airway lumen.

Single cells were scattered widely throughout the airways and parenchyma, but in 10 of the 12 lungs more than half of the total identified were in alveolar ducts and alveoli. In the case of two animals all the single cells were found at these sites, and none were present in bronchi and bronchioles. Neuroepithelial bodies were typically found at points of branching of airways, and the largest such structures were located in the small bronchi and bronchioles. In contrast to the single cells, in 10 of the 12 lungs studied more than $65 \%$ of the total were in bronchi and bronchioles. Of the remainder, located in the parenchyma, a large proportion were in alveolar ducts (fig 3). Those situated in alveoli were almost always sited on the alveolar wall immediately adjacent to an alveolar duct so as to be separated from it by alveolar septa only.

Immunostaining for neurone specific enolase showed some but not all cells immunoreactive for calcitonin to be positive. It was particularly noticeable that whereas most neuroepithelial bodies stained diffusely with the method solitary cells appeared not to stain.

\section{Discussion}

Fröhlich in 1949 was probably the first to appreciate fully that the clear cells (helle Zellen) of the airways occurred both singly and in clusters (knoetchen). ${ }^{2}$
Subsequently a large body of work has greatly increased our knowledge of these bronchopulmonary endocrine cells, which have since been observed in some non-mammalian as well as most mammalian species. ${ }^{514}$ The name neuroepithelial body was given to the corpuscular cell clusters, ${ }^{5}$ which appear to differ in certain respects from the solitary endocrine cells, not only with regard to their structural characteristics ${ }^{15}$ but also with regard to their response to experimental stimuli. ${ }^{10}$

Although the true embryological origin of these cells is still a subject of debate, they have certain features strongly supporting their inclusion in the so-called APUD system of cells. ${ }^{6}$ They take up amine precursors such as 5-hydroxytrytophan and show formaldehyde induced fluorescence, which microspectrographically has an emission spectrum characteristic of 5-hydroxytryptamine. This substance is localised in neurosecretory (dense core) granules. ${ }^{3}$ In addition to their content of amine, evidence suggesting the existence in neuroepithelial bodies of a peptide substance was provided by further microspectrographic study, ${ }^{16}$ and several different such substances have now been identified within solitary cells and neuroepithelial bodies. ${ }^{17}$ One such substance is calcitonin, which has been found in both solitary endocrine cells ${ }^{18}$ and neuroepithelial bodies ${ }^{4}$ of human lung. We have demonstrated by immunohistochemical methods the presence of this hormone, or a closely related peptide cross reacting with it, in the bronchopulmonary endocrine cells of the lung of the normal adult rat. It is of widespread distribution in solitary cells and neuroepithelial bodies throughout the airways and parenchyma (figs 1-3). Both of these classes of cells occur at all sites, but there is a distinct tendency for neuroepithelial bodies to occur in the bronchi and bronchioles rather than in the alveolar ducts and alveoli; and the reverse is the case for solitary cells, which are most often found in the parenchyma.

The presence of endocrine cells in alveolar ducts and alveoli has been described several times, but not apparently in such large numbers. ${ }^{1019}$ We cannot be certain that some of them were not derived either during life or at the time of fixation of the lungs by desquamation from the airways. The arrangement of most of these cells is, however, strongly suggestive of their normal presence at this site during life. Whether solitary cells or neuroepithelial bodies, they all showed excellent cytological preservation and appeared to be an integral part of the alveolar epithelium. When situated in alveolar ducts, neuroepithelial bodies were characteristically arranged on a distinct elevation in the lining of the duct, giving a typical corpuscular appearance (fig 3 ).

In addition to the pattern of distribution of 
immunoreactive solitary cells and neuroepithelial bodies, the large number of the latter found in the present study as well as the overall size of the total population merit comment. In a previous study of endocrine cells of human lungs, calcitonin was found to be rarely present in neuroepithelial bodies and to be largely confined to solitary endocrine cells. ${ }^{4}$ The presence of large numbers of immunoreactive neuroepithelial bodies in the present study may represent a species difference, or may reflect a physiological variability in the secretion of peptides by such cells occurring under different circumstances. Ignorance of the true function of these components prevents further speculation on this point. Although we have made no attempt to quantify it, the overall size of the endocrine cell population found in this study is also of interest, since the adult rat is usually regarded as unsuitable for studies of this kind owing to the alleged paucity of such cells. ${ }^{78}$ We believe that this is largely a consequence of the techniques used to demonstrate them. For example, unless frozen sections or freeze dried tissue are used, silver impregnation methods such as those of Grimelius and Bodian reveal very few of the endocrine cells actually present. This appears to be a feature of the golden hamster as well as the rat, since failure of lung tissue from the former fixed in formaldehyde, paraformaldehyde, or Bouin's solution to take up silver has also been demonstrated." The same authors also showed that fluorescence methods (the Falck-Hillarp and modified Eaton-Fedde techniques) revealed many more endocrine cells in the airways of the same species than did silver impregnation methods performed on adjacent tissue sections.

Despite the prevalence of endocrine cells immunoreactive for calcitonin in our present study, they probably still represent only a subpopulation of the total endocrine cell complement. In this regard it is interesting that whereas most of the neuroepithelial bodies immunoreactive for calcitonin showed positive immunostaining with antisera to neurone specific enolase most solitary cells, including those immunoreactive for calcitonin, did not. Occasionnally, neurone specific enolase positive cells were seen which appeared not to contain calcitonin. There are several possible explanations for this, including experimental artefact. For example, neurone specific enolase is a soluble enzyme that is sensitive to methods of fixation and antisera to it are often of variable affinity and avidity. False negative results may therefore occur. Not all peptide secreting cells, however, appear to contain neurone specific enolase (for example, those of the parathyroid gland) ${ }^{20}$ In the present case, the fact that most neuroepithelial bodies were positive for this enzyme whereas most solitary cells were not is of interest, and may possibly indicate a different embryological origin in that the former may be truly of neural derivation whereas the latter may not. Controversy about the embryological origin of bronchopulmonary and gastrointestinal endocrine cells continues, ${ }^{21}{ }^{22}$ and although neurone specific enolase has been well demonstrated in endocrine cells of human fetal lungs ${ }^{23}$ it is by no means proved that all such cells contain the enzyme.

We cannot be certain of the function of these cells either in health or in disease. Other peptides have been found in bronchopulmonary endocrine cells of normal lungs, including gastrin releasing peptide and leu-enkephalin. ${ }^{44}$ In health these peptides may act locally, perhaps to regulate the secretory activity of adjacent cells (paracrine function), or perhaps systemically (endocrine function). Adrenocorticotrophin may appear within such cells in diseased lungs. ${ }^{24}$ Calcitonin is also implicated in various forms of pulmonary disease. For example, hypercalcitoninaemia or hypercalcitoninuria has been reported in association with primary bronchogenic carcinoma (especially "oat cell" carcinoma, but also adenocarcinoma $)^{25}$; with chronic mucopurulent bronchitis ${ }^{26}$; and with emphysema, tuberculosis, and pneumonia. ${ }^{27}$ It has been suggested that this may be a consequence of hyperplasia of cells containing calcitonin, ${ }^{28}$ a phenomenon recently demonstrated in the case of endocrine cells in ectatic bronchi, and in lungs bearing carcinoid neoplasms and carcinomas. ${ }^{29}$

Further study of normal and diseased lungs may reveal the role of this series of cells in health and disease.

We would like to thank Mr GDD Laing for his invaluable technical assistance and Miss $C$ Youd for typing the manuscript. This work was supported by a grant from the Mersey Regional Health Authority.

\section{References}

1 Feyrter F. Zur Pathologie des argyrophilen hellezellen-Organes im Bronchialbaum des Menschen. Virchows Arch Path Anat Physiol 1954;325:723-32.

2 Fröhlich F. Die "helle-Zelle" der Bronchialscheimhaut und ihre beziehungen zum Problem der Chemoreceptoren. Frankfurter Zeitschrift Pathologische 1949; 60:517-59.

3 Lauweryns JM, Cokelaere M, Theunynck P. Serotonin producing neuroepithelial bodies in rabbit respiratory mucosa. Science 1973;180:410-3.

4 Cutz E, Chan W, Track NS. Bombesin, calcitonin, and leu-enkephalin immunoreactivity in endocrine cells of human lung. Experientia 1981;37:765-7.

5 Lauweryns JM, Cokelaere M, Theunynck P. Neuroepithelial bodies in the respiratory mucosa of various 
mammals: a light optical, histochemical, and ultrastructural investigation. $Z$ Zellforsch Mikrosk Anat 1972; 135:569-92.

6 Pearse AGE. The cytochemistry and ultrastructure of polypeptide hormone-producing cells of the APUD series and the embryologic, physiologic, and pathologic implications of the concept. J Histochem Cytochem 1969;17:303-13.

7 Moosavi H, Smith P, Heath D. The Feyrter cell in hypoxia. Thorax 1973;28:729-41.

8 Jeffery PK, Reid L. New observations of rat airway epithelium: a quantitative and electron microscopical study. J Anat 1975;120:295-320.

9 Sternberger LA. The unlabelled antibody peroxidaseantiperoxidase (PAP) method. In: Sternberger LA Immunocytochemistry. New York: John Wiley, 1979:104-69.

10 Taylor W. Pulmonary argyrophil cells at high altitude. J Pathol 1977;122:137-44.

11 Palisano JR, Kleinerman J. APUD cells and neuroepithelial bodies in hamster lung: methods, quantitation, and response to injury. Thorax 1980; 35:363-70.

12 Lauweryns JM, Peuskens JC. Argyrophil (kinin and amine producing?) cells in human infant airway epithelium. Life Sci 1969;8:577-85.

13 Lauweryns JM, Cokelaere M, Theunynck P, Deleersnyder $M$. Neuroepithelial bodies in mammalian respiratory mucosa: light optical, histochemical, and ultrastructural studies. Chest 1974;65:225-95.

14 Cook RD, King AS. A neurite-receptor complex in the avian lung: electron microscopical observations. Experientia 1969;25:1162-3.

15 Hage E. Electron microscopic identification of several types of endocrine cells in the bronchial epithelium of human foetuses. Z Zellforsch 1973;141:401-12.

16 Lauweryns JM, Liebens $M$. Microspectrography of formaldehyde and fluorescamine-induced fluorescence in rabbit pulmonary neuroepithelial bodies: demonstration of a new, probably polypeptide intracytoplasmic substance. Experientia 1977;33:1510-1.

17 Gould VE. The endocrine lung. Lab Invest 1983; 48:507-9.
18 Becker KL, Monaghan KG, Silva OL. Immunocytochemical localization of calcitonin in Kulchitsky cells of human lung. Arch Pathol Lab Med 1980;104:196-8.

19 Edmondson NA, Lewis DJ. Distribution and ultrastructural characteristics of Feyrter cells in the rat and hamster airway epithelium. Thorax 1980; 35:371-4.

20 Pearse AGE. Neuroendocrine tumours and hyperplasia. In: Filipe MI, Lake BD, eds. Histochemistry in pathology. Edinburgh: Churchill Livingstone, 1983:274-85.

21 Pearse AGE, Takor Takor T. Embryology of the diffuse neuroendocrine system and its relationship to the common peptides. Fed Proc 1979;38:2288-94.

22 Sidhu GD. The endodermal origin of digestive and respiratory tract APUD cells. Am J Pathol 1979;96:5-20.

23 Wharton J, Polak JM, Cole GA, Marangos PJ, Pearse AGE. Neuron specific enolase as an immunocytochemical marker for the diffuse neuroendocrine system in human fetal lung. J Histochem Cytochem 1981; 29:1359-64.

24 Tsutsumi Y, Osamura RY, Watanabe K, Yanaihara N. Immunohistochemical studies on gastrin-releasing peptide and adrenocorticotropic hormone-containing cells in the human lung. Lab Invest 1983;48:623-32.

25 Becker KL, Nash DR, Silva OL, Snider RH, Moore $\mathrm{CF}$. Urine calcitonin levels in patients with bronchogenic carcinoma. JAMA 1980;243:670-2.

26 Galan Galan F, Hurtado J, Cano RP, Peralta MG. High plasma calcitonin concentrations in chronic bronchitis. Br Med J 1982;285:850-1.

27 Becker KL, Nash D, Silva OL, Snider RH, Moore CF. Increased serum and urinary calcitonin in patients with pulmonary disease. Chest 1981;79:211-6.

28 Becker KL, Silva OL, Hypothesis: The bronchial Kulchitsky $(\mathrm{K})$ cell as a source of humoral biologic activity. Medical Hypotheses 1981; 7:943-9.

29 Memoli VA, Linnoila I, Warren WH, Rios-Dalenz J, Gould VE. Hyperplasia of pulmonary neuroendocrine cells and neuroepithelial bodies. Lab Invest 1983;48:57A (abstract). 